Zombai-Kovács MÁté ${ }^{-}$Havran ZsolT ${ }^{2}$

Játék Vagy valóság? Alternatív adatbázis

HASZNÁLATA A HIVATÁSOS LABDARÚGóK

ÉRTÉKELÉSÉHEZ KAPCSOLÓDÓ STATISZTIKAI-

ÖKONOMETRIAI SZÁMÍTÁSOK SORÁN

GAME OR REALITY? USING ALTERNATIVE DATABASE

FOR STATISTICAL AND ECONOMETRIC ANALYSIS OF THE

MARKET VALUE OF PROFESSIONAL FOOTBALL PLAYERS

A tanulmány $y^{3}$ célja, hogy megvizsgálja, milyen mértékben alkalmazható alternatív adatbázis a hivatásos labdarúgók értékeléséhez. Az egyre jelentösebb üzletté váló hivatásos labdarúgás egyik legföbb értékteremtö tényezöi maguk a hivatásos játékosok, ezért kiemelten fontos, hogy teljesítményük és piaci értékük minél pontosabban számszerüsithetö legyen. Cikkünkben a FIFA Electronic Arts videojáték adatbázisának kutatási célú használhatóságát ismertetjük. Kutatási kérdésünk, hogy ez az adatbázis megfelelö-e leíró statisztikák, korreláció-analizis és regressziós becslések alkalmazására. Eredményeink szerint az adatbázis használatának számos elönye van a többi, szabadon elérhetö adatbázishoz képest, és mind a tudományos elemzések, mind pedig a hivatásos labdarúgás érintettjei számára jó lehetöséget jelent statisztikai és ökonometriai kutatások elvégzésére.

Kulcsszavak: hivatásos labdarúgás, játékospiac, játékjog értékelés, futball ökonometria

The purpose of this study is to examine the feasibility of using an alternative database for analysing the value of professional football players. Professional football has become an important business and professional players are one of the key value drivers, so it is vital to quantify their performance and market value as accurately as possible. This article introduces the academic utility of the FIFA Electronic Arts Video Game Database. The research question is whether this database is appropriate for using descriptive statistics, correlation analysis, and regression estimates. According to our results, the use of the database has many advantages over other freely available databases and provides a good opportunity

\footnotetext{
${ }^{1}$ egyetemi hallgató, Budapesti Corvinus Egyetem

${ }^{2}$ adjunktus, Budapesti Corvinus Egyetem, Vállalatgazdaságtani Intézet

${ }^{3}$ A tanulmány Zombai-Kovács Máté: „A topbajnokság hatás - avagy a labdarúgók piaci értékének vizsgálata az ökonometria eszköztárának felhasználásával” címü, 2018-ban született TDK-dolgozat átírt változata. A dolgozat elkészítéséhez nyújtott segítségéért köszönetünket fejezzük ki Dr. András Krisztinának. Kézirat lezárva: 2019. november.
}

DOI: 10.14267/RETP2020.03.16 
both for scientific analysis and for stakeholders of professional football to perform statistical and econometric research.

Key words: professional football, transfer market, players' value evaluation, football econometrics

A hivatásos labdarúgás hatalmas médiafigyelem mellett, komoly globális üzletként müködik [András et al., 2012]. A világszerte közvetített mérkőzések, a minden földrészről érkező szurkolók és szponzorok mellett a futball globális müködését jól szemlélteti annak játékospiaci müködése is. A hivatásos klubok egyre nagyobb számban alkalmaznak külföldi játékosokat, egyre több országban figyelik a tehetségeket. A klubok legfőbb erőforrása maga a játékos, kiemelten pedig a legnagyobb tehetségek, hiszen az ö sportteljesítményük és médiaszereplésük teremti meg a klubok üzleti működésének alapjait. Így komoly verseny alakult ki a játékosok megszerzéséért, egyre fontosabb szempont lett az, hogy milyen áron tudják megvásárolni őket.

A tehetségek azonosítása és kiválasztása nem egyszerü feladat. Manapság már nem csak a legnagyobb klubok privilégiuma a megfigyelőhálózat müködtetése, valamint az interneten is egyre több adat érhető el a labdarúgók teljesítményéről. Ha egy klub relatíve alacsony áron jut olyan játékoshoz, aki a csapat játékszerkezetébe és a klub imázsába is illeszkedik, az versenyelönyt jelenthet mind a sportszakmai, mind pedig a pénzügyi értelemben vívott verseny során is. Azok a klubok, akik az elérhető adatokat ismerik és jól használják, könnyebben találhatják meg a számukra megfelelő játékost, versenytársaiknál gyorsabban léphetnek.Ezért érdemes a játékosaik kiválasztása során is innovatívnak lenni.

A játékosok reális értékének meghatározásához meg kell ismerni, milyen tényezők befolyásolhatják azt. Tanulmányunkban bemutatjuk a hivatásos labdarúgás transzferpiacának jellegzetességeit és aktualitásait. Ismertetjük a hivatásos labdarúgók értékét meghatározó tényezőket és a nemzetközi szakirodalomban megjelent, a játékosok értékelésével foglalkozó tanulmányokat, továbbá a lehetséges játékospiaci adatforrások előnyeit és hátrányait.

Kutatásunk újszerüségét annak módszertani része, azon belül is a felhasznált adatbázis jelenti. Az Electronic Arts által készített FIFA 18 videojáték egy olyan számítógépes szoftver, amelyet szakértők segítségével készítenek el, és több mint 17 ezer játékos valós adatain (például életkor, játéktudás) alapul. Feltételezésünk szerint a korábbi cikkekben használt módszertanok az általunk felhasznált nagyméretű adatbázison is jól alkalmazhatók, valamint bizonyos kutatásoknál pontosabb eredményeket is kaphatunk adatbázisunk karakterisztikáiból adódóan. Kutatási kérdésünk: hogyan használható a számítógépes játék adatbázisa a hivatásos játékosok értékeléséhez kapcsolódó elemzések során. Tanulmányunkban példákat mutatunk a leíró statisztikák, a korreláció-analízis illetve a regressziós becslések alkalmazására is.

\section{Szakirodalmi ÖsSzeFoglaló}

A sportban az éles verseny kialakulása [Szymanski-Kuypers, 1999], majd a globalizáció, a telekommunikáció fejlődése és a média térnyerése lehetővé tette az üzlet kialakulásának alapvető feltétele, a fogyasztói igény megjelenését, megalapozva ezzel a hivatásos sport kialakulását, a hivatásos sportolók megjelenését [András, 2004]. Bühler [2006] a labdarúgás üzleti jelentőségét három tényezőre vezeti vissza: a klubok futballtársaságokká alakulására, a futball piacain forgó hatalmas mennyiségü pénzre, és a nagy és egyre növekvő számú érintettre. András [2004] alapján a labdarúgáshoz kapcsolódó piacnak tekinthetők mindazon források, amelyek a futballtár- 
saságok bevételeit biztosítják, s ezen bevételi források egy-egy piacként elemezhetők. Ilyen formában megkülönböztethetjük a fogyasztói piacot, a közvetítési jogok piacát, a szponzori piacot, a merchandising-piacot és a kutatásunk szempontjából kiemelt jelentőséggel bíró játékospiacot. Az említett első négy piacról származó bevételeket a csapatok a játékospiacon egészíthetik ki vagy költhetik el attól függően, hogy a mindenkori vezetés milyen átigazolási politikával kíván a klub sikeressége érdekében tenni. A játékospiac egy olyan speciális munkaerőpiac, ahol a szerződés tárgya a játékjog használatának meghatározott időtartamra vonatkozó átruházása [András, 2003]. E piac az elmúlt évtizedek során egyre jelentősebb szerephez jutott a labdarúgás területén, mivel végső soron maga a játékosok teljesítménye határozza meg egy-egy sportvállalat sikerességét [Havran, 2016]. Az Európai Labdarúgó Szövetség (UEFA) által készített jelentés alapján elmondható, hogy a labdarúgó vállalatok mérlegében a labdarúgók játékjoga az egyik legnagyobb értékkel bíró tétel az eszközök között, stabilan az összes eszközállomány 20-25 százalékát teszik ki [UEFA 2018: 106].

A kezdeti statisztikai és ökonometriai kutatások a hivatásos sport területén főként a klubok és játékosaik teljesítményének [Bennett-Flueck, 1983; Berri, 1999; Carmichael et al., 2000] és egyes mérkőzések eredményének [Dixon-Robinson, 1998; Maher, 1982; Stern, 1991] előrejelzésére irányultak [Tunaru et al., 2003]. A hivatásos labdarúgók csapatuk számára nyújtott teljesítményének értékével kapcsolatos kutatások a játékosok szabad nemzetközi mozgását lehetővé tevő Bosman-szabály bevezetése után terjedtek el [Dawson et al., 2000; Szymanski-Smith, 1997; Szymanski-Kuypers, 1999]. Az első tanulmányok föként a potenciális magyarázó változók azonosítására, az általánosságban érvényes összefüggések meghatározására irányultak. Szymanski és Kuypers [1999] kutatásukban erős korrelációt fedeztek fel az egyes klubok által játékosfizetésekre elköltött összegek nagysága és az adott együttes pályán nyújtott teljesítménye között.

Az ezt követö években olyan összetett explicit modellek is létrejöttek a hivatásos labdarúgók piaci értékére vonatkozóan, mint például Tunaru, Clark és Viney [2003] opcióárazási modellje. A korábbi kutatások eredményei alapján dolgozatunkban két csoportba soroljuk a hivatásos labdarúgók piaci értékét meghatározó tényezőket, ahol a játékosok teljesítményét és képességeit leíró, illetve az élettani és egyéni jellemzőket tömörítő változók alkotnak egy-egy csoportot. Ennek megfelelően a releváns szakirodalmak eredményeit is hasonló csoportositásban mutatjuk be.

Már az 1990-es években több kutató szignifikáns pozitív kapcsolatot állapított meg a labdarúgó által lejátszott mérkőzések száma és átigazolási díja között. Közülük többen a teljes karrier során lejátszott összes mérkőzést figyelembe vették [Carmichael-Thomas, 1993; DobsonGerrard, 1999], mások csak a legutolsó bajnoki szezon statisztikáit vették alapul [Reilly-Witt, 1995; Speight-Thomas, 1997], s olyan kutatás is akadt, amelyben külön változóként szerepelt a játékos jelenlegi csapatában lejátszott, és a más együttesek színeiben teljesített mérkőzéseinek száma [Carmichael et al., 1999].

Hasonló eredmények születtek az adott játékos válogatott mérkőzéseinek számát illetően. Carmichael és szerzőtársai [1999] kutatásukban szignifikáns pozitív kapcsolatot mutattak ki a válogatott mérkőzések száma és a piaci ár között. Frick és Lehmann [2001] a pozitív lineáris kapcsolat mellett a negatív négyzetes kapcsolatot is szignifikánsnak találta, amit a válogatottság csökkenő határhozadéka magyarázhat. A legutóbbi kutatások közül több kétértékü, dummy változóként szerepelteti a válogatottságot [Sæbø-Hvattum, 2015; Wicker et al., 2013] azaz nem a lejátszott mérkőzések számának, hanem magának a válogatottság tényének hatásait vizsgálja.

A rúgott gólok és az adott gólpasszok száma is gyakran megjelenik a labdarúgók piaci értékét becslő modellek magyarázó változói között, de az ezen tényezőkhöz kapcsolódó eredmé- 
nyek nem teljesen egybehangzók a sportközgazdászok körében. Preston [2014] az angol, Frick és Lehmann [2001] a német piacon vizsgálódva találta szignifikánsan pozitívnak a rúgott gólok számának hatását, míg van den Berg [2011] - az angol Premier League átigazolásaira vonatkozó - kutatása során nem talált szignifikáns kapcsolatot a játékos által szerzett gólok száma és átigazolási díja között. Majewski [2016] kifejezetten támadójátékosokra specifikált kutatása mind rúgott gólok, mind gólpasszok tekintetében szignifikánsan pozitív kapcsolatot mutatott ki, ezzel szemben Kiefer [2012], valamint Patai és Popper [2014] kutatása során is csak a lőtt gólok számának hatása bizonyult szignifikánsnak a 2012-es Európa-bajnokságon szereplő labdarúgók piaci értékének változásában, a kiosztott gólpasszok száma nem.

Az utóbbi években több tanulmány is vizsgálta a labdarúgók jobb vagy bal lábas voltának és gyengébb lábával való ügyességének hatásait piaci értékére vonatkozóan [van den Berg, 2011; van Ruijg-Ophem, 2014; Sæbø-Hvattum, 2015]. Eredményeik alapján azt mondhatjuk, a játékospiacon a bal és jobb lábas játékosok szinte tökéletes helyettesítőként jelennek meg, tekintve, hogy az említett kutatások nem mutattak ki szignifikáns kapcsolatot az erösebb láb és a piaci érték között. Azon labdarúgók esetében, akik mindkét lábukkal hasonlóan ügyesek, Sæbø és Hvattum [2015] kutatásukban szignifikáns felárat mutattak ki, melynek magyarázataként ezen játékosok sokoldalúsága szolgálhat.

A korábban említett, a labdarúgók teljesítményére vonatkozó változók mellett néhány közgazdász további tényezők hatásait is vizsgálta. Ilyen például a játékosok lövés- és passzpontossága [Wicker et al., 2013], amely a hatékonyság mérőszáma lehet, vagy éppen a mérkőzések során kapott sárga és piros lapok száma [van Ruijg-Ophem, 2014; Majewski, 2016], amely az adott labdarúgó pályán tanúsított magatartására, higgadtságára vonatkozóan szolgáltat információkat, ám ezen változók hatása általában nem bizonyult szignifikánsnak.

A megfelelő, objektív teljesítményváltozók felkutatásának nehézsége és potenciálisan nagy száma miatt az utóbbi időben több sportközgazdász olyan aggregált mérőszámokat használt fel kutatásához, amelyek széles körben ismertek, és különböző, szakértők által elóállított algoritmusokon alapulnak. Tunaru és szerzőtársai [2003] kutatásuk során az Opta Index értékét használták fel, amelyet az angol Premier League-ben szereplő labdarúgók formájának értékelésére alakítottak ki a játékosok teljesítményének mérésére specializálódott statisztikusok. Az index értéke a több mint 300 bemeneti értékkel (például pontos lövések, passzok, szabályos szerelések száma) rendelkező mérkőzésenkénti osztályzat hatfordulós mozgóátlagából alakul ki, így - annak ellenére, hogy a közelmúlt teljesítményét rendkívül jól osztályozza - a labdarúgók képességeinek pontos meghatározására nem alkalmas.

Sæbø és Hvattum 2015-ös, a játékospiac hatékony müködésének kérdését tárgyaló kutatásukban egy objektív mutatószámot hoztak létre labdarúgók értékelésére különböző teljesítményadatok felhasználásával, majd - más potenciális magyarázó változók mellett - ezt a mutatószámot használták fel az átigazolási árakat meghatározó tényezők azonosítását célzó modellükben. A mutatószám, amelyet egy lineáris regressziós modell segítségével alakítottak ki, az adott játékos csapatának eredményeihez hozzáadott értékét becsüli, s kialakítása során olyan tényezőkre is korrigáltak a szerzők, mint például a büntetőlapok vagy a hazai pálya előnye.

A labdarúgók piaci értékét meghatározó élettani és egyéni jellemzőket kutató sportközgazdászok körében általánosan elfogadott [Frick, 2007], hogy a játékosok életkora nagy befolyással bír piaci értékükre nézve, emellett döntő többségük egyetért abban is, hogy pozitív lineáris és negatív négyzetes hatás jellemző. Ennek magyarázata abban rejlik, hogy egy labdarúgó pályafutásának első felében (körülbelül 25-26 éves korig) a kor növekedése jobb teljesítménnyel és nagyobb tapasztalattal párosul, ám a karrier csúcspontját elérve a többletévek már a gyengülő fizikai álla- 
potot, alacsonyabb teherbírást és a visszavonulás közeledését jelenthetik [van den Berg, 2011; Carmichael et al, 1999; Sæbø-Hvattum, 2015].

A labdarúgók sérülékenységének piaci értékre gyakorolt hatásaival szintén több tanulmány foglalkozott, ám az adatok pontatlansága, hiányossága és alapvetően alacsony száma nehézkessé teszi e tényező vizsgálatát [Patai-Popper, 2014]. Tunaru és szerzőtársai [2003] kutatásuk során úgy találták, hogy a sérülések hatásainak modellezésére a Poisson-folyamat lehet a legmegfelelőbb, amely ritka események vizsgálatára alkalmas, és évtizedek óta sikeresen alkalmazzák például biztosítások terén. Van den Berg [2011] más megközelítésben vizsgálta a játékosok sérülékenységének hatásait: az elmúlt szezonban sérülten töltött hetek számát is szerepeltette az átigazolási árra vonatkozó regressziós modelljében, ám eredményei alapján e változó hatása nem bizonyult szignifikánsnak.

Az egyes posztokon szereplő labdarúgók piaci értékében mutatkozó különbségek vitatottak a kutatók körében. Reilly és Witt [1995] kutatásukban a támadójátékosok esetében találtak szignifikáns felárat, emellett a csatárok kitüntetett szerepét jelzi az is, hogy egyes tanulmányok kifejezetten az ezen a poszton szereplő játékosokra fókuszálnak [Majewski, 2016]. Eschweiler és Vieth 2004-es, a német Bundesliga átigazolásait vizsgáló kutatásukban a védőjátékosok, középpályások és támadók kapusokhoz viszonyított szignifikánsan magasabb árát állapították meg. Ezzel szemben Preston [2014], Ruijg és Ophem [2014], valamint Sæbø és Hvattum [2015] eredményei alapján a játékosok posztja nem befolyásolja szignifikánsan piaci árukat.

A labdarúgók nemzetiségének piaci értékre gyakorolt hatásait egyes kutatók jelentősen eltérő megközelítésben vizsgálták. Van den Berg [2011] az angol Premier League átigazolásait vizsgáló tanulmányában három csoportot különböztetett meg, egyesült királyságbeli, egyéb európai uniós tagországból származó és az EU-n kívülről érkező labdarúgókat, így vizsgálva a Premier League magasabb iramához és nagyobb fizikalitásához való alkalmazkodás nehézségeinek hatását a játékosok értékére vonatkozóan. Van den Berg feltevésével bizonyos mértékig ellentétes megállapításra jutott Sæbø és Hvattum [2015], akik szignifikánsnak találták a dél-amerikai labdarúgók magasabb piaci árát egyéb országok játékosaihoz képest. Eschweiler és Vieth [2004] más oldalról közelítették a nemzetiség kérdését, és a labdarúgók szülőhazájának FIFA koefficiensét szerepeltették modelljükben. Eredményeik alapján a magasabban rangsorolt országokból érkező labdarúgók piaci értékében szignifikáns felár jelentkezik.

Mindezen tényezők mellett kiemelendő még Frick és Lehmann 2001-es tanulmányában megjelenő, az adott labdarúgó klubcsapatának országára vonatkozó változó. Kutatásuk során szignifikánsnak találták a nyugat-európai együttestől vagy dél-amerikai klubtól a német Bundesligában szereplő csapathoz igazoló játékosok felárát más országokból érkező labdarúgókhoz képest. Friss kutatások egyre többet foglalkoznak a játékosok népszerüsége és becsült értéke közötti összefüggésekkel, amelyek szerint föleg a közösségi médiában elért követők száma lehet releváns [Ante, 2019].

\section{Módszertan}

Kutatásunk során arra a kérdésre keressük a választ, hogyan alkalmazható a FIFA Electronic Arts számítógépes játék adatbázisa a hivatásos játékosok értékelése során. Kutatási kérdésünk relevanciája a labdarúgók piaci értékelésével foglalkozó tanulmányok által tradicionálisan használt adatbázisok hiányosságaiból, potenciális torzításaiból, valamint a kutatási terület újszerü, innovatív megközelítésére való törekvésből ered. Elöször ismertetjük a témában elérhető adatbázisokat, majd a FIFA adatbázison elvégezni tervezett statisztikai elemzéseket. 
Európában a labdarúgók értékének meghatározásával több szakértő, vállalkozás is foglalkozik, ezek közül kiemelkedik három, amelyeket sportközgazdászok használtak a játékosok becsült értékének meghatározása során (1. táblázat).

1. táblázat: Hivatásos labdarúgók értékének becsléséhez elérhető adatbázisok

\begin{tabular}{c|l}
\hline \multicolumn{1}{c|}{ Adatbázis } & \multicolumn{1}{c}{ Módszer és jellemzők } \\
\hline $\begin{array}{c}\text { CIES Football } \\
\text { Observatory [CIES, } \\
\text { 2019] }\end{array}$ & $\begin{array}{l}\left.\text { Részletes regressziós számításokon alapszik ( } \mathrm{R}^{2}=76 \%\right) \text {. Becsült érték és } \\
\text { átigazolási összeg becsléseket is tartalmaz. Közel 5000 korábbi transzfer } \\
\text { adatai alapján készítették el. Csak a Big Five (Anglia, Németország, } \\
\text { Spanyolország, Olaszország, Franciaország) bajnokságok játékosaira } \\
\text { vonatkozóan találhatók benne adatok. }\end{array}$ \\
\hline $\begin{array}{c}\text { Transfermarkt.de } \\
\text { [Transfermarkt, 2019] }\end{array}$ & $\begin{array}{l}\text { Szinte minden bajnokság, és számos alacsonyabb osztály adatai is } \\
\text { szerepelnek benne. Pontatlanabb számítások: statisztikai becslések } \\
\text { mellett benchmark és regisztrált fórumozók értékelései alapján is } \\
\text { dolgoznak [Müller et al., 2017]. Transzparens és reprodukálható. }\end{array}$ \\
\hline KPMG Advisory Sport & $\begin{array}{l}\text { 2018-ban indították el, a CIES-nél pontosabb becslési modellként } \\
\text { hivatkozik rá a KPMG tanácsadó vállalat. Az Opta-val (sportstatisztikai } \\
\text { adatokkal foglalkozó vállalat) együttmüködve készítették el. 11 } \\
\text { bajnokságra terjed ki: Argentína, Belgium, Brazília, Anglia, Franciaország, } \\
\text { Németország, Olaszország, Hollandia, Portugália, Spanyolország és } \\
\text { Törökország. Jelenleg csak fizetős szolgáltatásként érhető el. }\end{array}$ \\
\hline
\end{tabular}

Forrás: saját szerkesztés

Az 1. táblázatban összefoglalt hátrányok miatt, illetve a jövőbeli kutatások újszerü megalapozása érdekében jelen kutatás során annak jártunk utána, hogy milyen más, nagy mintát tartalmazó adatbázis (2. táblázat) állhat még rendelkezésre a játékosok teljesítményére és becsült értékére vonatkozóan.

2. táblázat: Alternatív megoldások a hivatásos labdarúgók értékének becsléséhez

\begin{tabular}{c|c}
\hline Adatbázis & Módszer és jellemzők \\
\hline $\begin{array}{c}\text { Mesterséges } \\
\text { intelligencia alapú } \\
\text { értékelés } \\
\text { [SAS, 2019] }\end{array}$ & $\begin{array}{c}\text { A SciSports és SAS vállalatok együttmüködésével jött létre. } \\
\text { 244 liga, } 90.000 \text { játékos, hetente } 2.000 \text { mérkőzés adatai szerepelnek } \\
\text { benne. Jelenleg csak fizetös szolgáltatásként érhető el. }\end{array}$ \\
\hline $\begin{array}{c}\text { Alternatív lehetőség: } \\
\text { FIFA Electronic Arts } \\
\text { [Kaggle, 2018] }\end{array}$ & $\begin{array}{c}\text { Évente frissül, relatíve sok játékos szerepel benne (mintegy 18 ezer). Több, } \\
\text { mint 150 változó szerepel benne. Nagy létszámú szakértői csapat értékeléseit } \\
\text { is használják. Túlságosan a játékfejlesztők motivációján alapulhat. }\end{array}$ \\
\hline
\end{tabular}


Kutatásunk tehát az Electronic Arts által készített FIFA videojáték-sorozat 2018-as kiadásának adatbázisára épül [Kaggle, 2018], amely csaknem 18 ezer hivatásos labdarúgóra tartalmaz több, mint 150 változóra vonatkozó megfigyeléseket. Ezek közül a releváns, kutatásba bevont változókat és azok hatásaival kapcsolatos előzetes várakozásainkat tartalmazza a 3. táblázat.

3. táblázat: A kutatásba bevont változók és azok hatásaival kapcsolatos előzetes várakozások

\begin{tabular}{|c|c|c|c|}
\hline Változó típusa & Változó neve & Rövidítés & Várt hatás \\
\hline Függö változó & Piaci érték & eur_value, logvalue & - \\
\hline \multirow{4}{*}{$\begin{array}{l}\text { Képességekre, } \\
\text { teljesítményre } \\
\text { vonatkozó }\end{array}$} & $\begin{array}{c}\text { Jelen képességek } \\
\text { aggregált mérőszáma (1-99) }\end{array}$ & overall & pozitív \\
\hline & $\begin{array}{c}\text { Fejlődési lehetőségek } \\
\text { aggregált mérőszáma (1-99) }\end{array}$ & potential & pozitív \\
\hline & $\begin{array}{l}\text { Speciális képességek } \\
\text { aggregált méröszáma }\end{array}$ & special & pozitív \\
\hline & Gyengébb láb ügyessége (1-5) & weak_foot & pozitív \\
\hline \multirow{5}{*}{$\begin{array}{c}\text { Élettani, } \\
\text { egyéni } \\
\text { jellemzökre } \\
\text { vonatkozó }\end{array}$} & Kor & age & $\begin{array}{c}\text { négyzetes, } 25-26 \text { éves } \\
\text { korig pozitív, majd } \\
\text { negatív }\end{array}$ \\
\hline & Sérülékenység & injury_prone_trait & negatív \\
\hline & Poszt & $\begin{array}{c}\text { kapus, vedo, } \\
\text { kozeppalyas, tamado }\end{array}$ & $\begin{array}{l}\text { támadóknál } \\
\text { pozitív }\end{array}$ \\
\hline & Származás (földrész) & $\begin{array}{c}\text { europa, delamer, } \\
\text { eszakamer, ausztesoc, } \\
\text { afrika, azsia }\end{array}$ & $\begin{array}{l}\text { Dél-Amerika esetében } \\
\text { pozitív }\end{array}$ \\
\hline & Topbajnokság & $\begin{array}{l}\text { premierl, primerad, } \\
\text { bundesl, seriea, frenchl }\end{array}$ & pozitív \\
\hline
\end{tabular}

Forrás: saját szerkesztés

Felhasznált adatbázisunk a hagyományosan alkalmazott adatforrások számos hátrányát kiküszöböli. Míg a CIES Football Observatory becslései kizárólag a Big Five bajnokságokra koncentrálódnak, valamint a KPMG piaci értékadatai is csak a legjelentősebb 11 bajnokságra elérhetők, a FIFA 18 videojáték adatbázisában megtalálható bajnokságok száma ezeknek többszöröse.

A Transfermarkt becsléseiben fellelhető szubjektív elemek (fórumozók véleménye) és egyszerüsítések (benchmark használata) is csak korlátozottan jelennek meg adatbázisunk értékeiben, hiszen egy közel 10 ezer főből álló szakértői csapat véleménye és statisztikái alapján alakítják ki a végleges adathalmazt. Mindemellett, több más piaci értékbecsléssel ellentétben a FIFA 18 adatbázisa ingyenesen és jól strukturáltan elérhető bárki számára a világhálón. Korlátjaként említhetjük, hogy a játékosok bizonyos szubjektív változóinak értékét a játékfejlesztők értékítélete, illetve egyéb motivációja is befolyásolhatja.

Tanulmányunkban statisztikai és ökonometriai módszerek segítségével vizsgáljuk adatbázisunk alkalmazhatóságát labdarúgók értékelésével, illetve a piaci értékeket befolyásoló tényezők azonosításával foglalkozó kutatások esetében. Adatbázisunk méretéből és jól strukturált 
természetéből adódóan megfelelö alapot biztosít a labdarúgók piaci értékének leíró statisztikák (elemszámok, átlagok, szórások) általi elemzésére. Ezen statisztikák hasznosak lehetnek többek között egyes bajnokságok, játékoscsoportok közötti átfogó különbségek feltárására, valamint a becsült piaci értékek és az elérhető potenciális magyarázó változók közötti általános kapcsolatok vizsgálatára.

A korreláció-analízis segítségével a kutatásba bevont változók közötti együttmozgások állapíthatók meg, ezzel lehetőséget nyújtva az előzetesen feltételezett kapcsolatok irányának validálására, azok erősségének meghatározására. Adatbázisunk karakterisztikáiból adódóan szintén jó lehetőséget biztosított a kutatásba bevont változók közötti együttmozgások vizsgálatára.

Regressziós modellek segítségével vizsgálhatjuk meg, hogy a korábban azonosított változók közötti kapcsolatok más tényezőkre való kontrollálás mellett is jelentősnek mutatkoznak-e, valamint, hogy a kapcsolatok, egymásra hatások hogyan számszerüsíthetők, hogyan értelmezhetők. Adatbázisunk tartalmazza a labdarúgók piaci értékének korábbi kutatások eredményei szerinti legjelentősebb magyarázó tényezőit, illetve azokra vonatkozó proxy változókat, így megfelelő keretet biztosít regressziós modellek futtatására is.

\section{EREDMÉNYEK}

A 4. táblázat az előzetes várakozásaink alapján potenciálisan legnagyobb magyarázó erővel bíró piaci értéket befolyásoló tényezők átlagát és szórását mutatja be az adatbázis egyes bajnokságok szerinti csoportokra bontott almintáin. A táblázatban jól megfigyelhetö, hogy az öt topbajnokságban játszó labdarúgók átlagos piaci értéke jelentősen meghaladja a más bajnokságokban szereplőkét.

Azt is láthatjuk, hogy a magasabb értékek nem tulajdoníthatók egyértelmüen a bajnokság szerepének, hiszen emögött fundamentumok is vannak, mindhárom képességekre és tehetségre vonatkozó magyarázó változó - az overall, a potential és a special változó - tekintetében átlagosan magasabb értékeket figyelhetünk meg a Big Five bajnokságok futballistáinál. Ahhoz, hogy megállapítsuk, származik-e szignifikáns felár magából a labdarúgó bajnokságából, kontrollálnunk kell a piaci értéket befolyásoló egyéb tényezőkre, nem szabad figyelmen kívül hagynunk az esetleges együttmozgásokat.

4. táblázat: A potenciálisan legnagyobb magyarázó erővel bíró magyarázó változókra vonatkozó átlagok és szórások alakulása bajnokságok szerinti alminták esetében

\begin{tabular}{c|c|c|c|c|c|c|c}
\hline Statisztika & $\begin{array}{c}\text { Teljes } \\
\text { adatbázis }\end{array}$ & $\begin{array}{c}\text { Premier } \\
\text { League }\end{array}$ & $\begin{array}{c}\text { Primera } \\
\text { División }\end{array}$ & $\begin{array}{c}\text { Bundes- } \\
\text { liga }\end{array}$ & Serie A & Ligue 1 & Egyéb \\
\hline $\begin{array}{c}\text { Játékosok } \\
\text { száma }\end{array}$ & 17994 & 654 & 602 & 537 & 559 & 598 & 15044 \\
\hline $\begin{array}{c}\text { Piaci érték } \\
\text { (millió } \boldsymbol{€})\end{array}$ & $\begin{array}{c}2,37 \\
(5,35)\end{array}$ & $\begin{array}{c}9,09 \\
(12,21)\end{array}$ & $\begin{array}{c}9,26 \\
(12,31)\end{array}$ & $\begin{array}{c}7,70 \\
(10,02)\end{array}$ & $\begin{array}{c}7,29 \\
(9,46)\end{array}$ & $\begin{array}{c}5,18 \\
(8,56)\end{array}$ & $\begin{array}{c}1,32 \\
(2,15)\end{array}$ \\
\hline Overall & 66,3 & $72,4(8,6)$ & $73,7(6,9)$ & $\begin{array}{c}72,4 \\
(7,1)\end{array}$ & $\begin{array}{c}72,6 \\
(7,0)\end{array}$ & $\begin{array}{c}70,5 \\
(6,6)\end{array}$ & $\begin{array}{c}65,1 \\
(6,2)\end{array}$ \\
\hline
\end{tabular}




\begin{tabular}{c|c|c|c|c|c|c|c}
\hline Potential & $\begin{array}{l}71,2 \\
(6,1)\end{array}$ & $78,3(5,6)$ & $78,6(5,1)$ & $\begin{array}{c}78,2 \\
(5,0)\end{array}$ & $\begin{array}{c}77,7 \\
(5,4)\end{array}$ & $\begin{array}{c}76,1 \\
(5,4)\end{array}$ & $\begin{array}{c}69,9 \\
(5,3)\end{array}$ \\
\hline Special & $\begin{array}{l}1594 \\
(272)\end{array}$ & $1729(296)$ & $1736(284)$ & $\begin{array}{c}1712 \\
(298)\end{array}$ & $\begin{array}{c}1694 \\
(308)\end{array}$ & $\begin{array}{c}1675 \\
(288)\end{array}$ & $\begin{array}{c}1572 \\
(261)\end{array}$ \\
\hline Age & $\begin{array}{c}25,1 \\
(4,6)\end{array}$ & $24,7(4,8)$ & $24,9(4,2)$ & $\begin{array}{c}24,2 \\
(4,4)\end{array}$ & $\begin{array}{c}25,3 \\
(4,9)\end{array}$ & $\begin{array}{c}24,2 \\
(4,5)\end{array}$ & $\begin{array}{c}25,2 \\
(4,6)\end{array}$ \\
\hline
\end{tabular}

Forrás: saját szerkesztés

Fontos megjegyezni, hogy a korrelációvizsgálatok során a logaritmizált piaci értéket használtuk fel az euróban mért piaci érték helyett. Ennek oka az az 1. ábra bal oldalán is megmutatkozó jelenség, miszerint a piaci érték az overall változó függvényében exponenciálisan növekszik. Ha az euróban vett piaci érték természetes alapú logaritmusát vesszük, és ezt az új változót (logvalue) ábrázoljuk az overall érték függvényében - ahogy az az 1. ábra jobb oldalán is látható -, közel lineáris kapcsolatot figyelhetünk meg. Figyelembe véve, hogy a labdarúgók piaci értékének varianciáját nagymértékben a képességekre és teljesítményre mutatkozó mérőszámok varianciája magyarázza, célszerủek tartjuk a logaritmizált függő változó kutatásunkhoz való felhasználását.

1. ábra: Az adatbázisban szereplö labdarúgók euróban mért és logaritmizált piaci értéke az overall változó függvényében
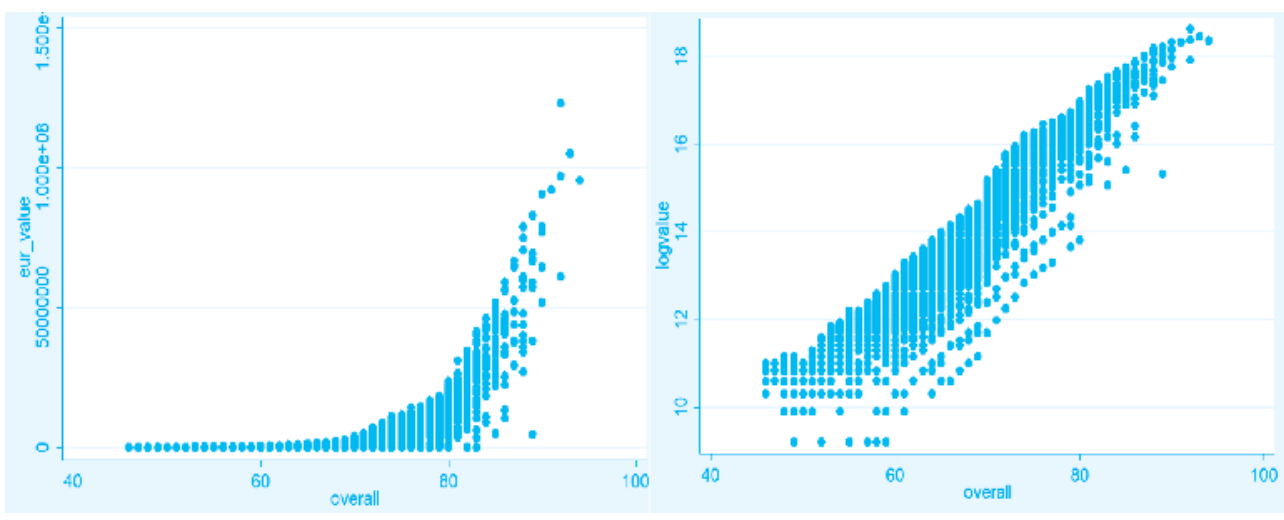

Forrás: saját szerkesztés, Stata 13 output

Ha a logaritmizált függő változó és a potenciális magyarázó változók közötti korrelációs kapcsolatot vizsgáljuk - ahogy az a 2. ábrán is megjelenik -, azt láthatjuk, hogy minden kutatásunkba bevont magyarázó változó piaci értékkel vett korrelációja statisztikailag szignifikáns 1 százalékos szignifikanciaszinten. Fontos megjegyezni, hogy a legerősebb kapcsolat az elözetes várakozásoknak megfelelően a játéktudásra vonatkozó változók esetében figyelhető meg, és egyedül az overall változó varianciája 88,68 százalékot magyaráz a piaci érték természetes alapú logaritmusának varianciájából.

Kutatásunk során a regressziós modellek kialakításához és futtatásához a Stata 13 programot használtuk fel. Összesen nyolc fő modellspecifikációt vizsgáltunk, amelyek közül négyben az euróban mért piaci érték, négyben pedig a piaci érték természetes alapú logaritmusa 
szerepel függő változóként. Mindkét csoporton belül lefuttattunk egy-egy olyan specifikációt, amelyben nem szerepelnek a származási helyre vonatkozó dummy változók, a potential változó és az injury_prone_trait dummy sem, de ezeken kívül minden korábban tárgyalt potenciális magyarázó változót tartalmaznak (I. és V. modellek). A II. és VI. modellekben a származási helyre vonatkozó változók is megjelennek, a III. és VII. modellekben mindezek mellett a potential változó is szerepel, míg a IV. és VIII. modellspecifikációk már a sérülékenységre vonatkozó változót is szerepeltetik, ezáltal az összes korábban tárgyalt potenciális magyarázó változót tartalmazzák.

2. ábra: Az euróban mért piaci érték természetes alapú logaritmusa és a tárgyalt potenciális magyarázó változók közötti korrelációs együtthatók

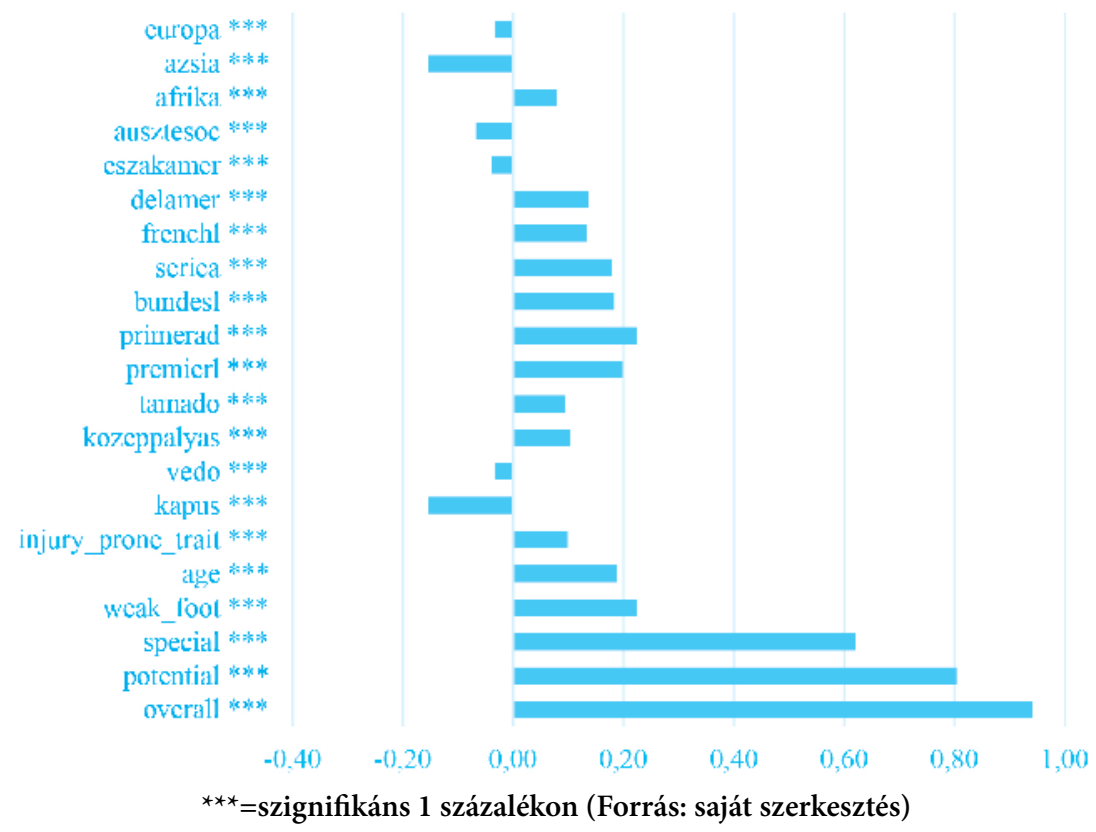

Összességében a vizsgált regressziós modellek robusztussága, kiváltképp a logaritmizált függő változójú specifikációk esetében tapasztalt - az 5. táblázatban is megjelenő - 97-98 százalék körüli $\mathrm{R}^{2}$ értékek alapján úgy gondoljuk, a kapott eredmények részben az Electronic Arts szakértöcsapata által végzett piaci értékbecslés metodológiáját tükrözik. Ezen eredmények szerint a futtatott modellek magyarázó változóinak varianciája együttesen a piaci érték természetes alapú logaritmusának varianciáját több mint 97 százalékban magyarázza.

Hasonlóan magas magyarázó erővel rendelkező modell szinte kizárólag akkor hozható létre, ha a függő változó értéke alapvetően a modellben szereplő magyarázó változók értékeinek valamiféle függvényeként áll elö, vagy legalábbis e magyarázó változók értékei is nagy szerepet töltenek be a függő változó értékének elóállítása során. Emiatt a regressziós modellek eredményei némileg torzítottak lehetnek, így elővigyázatossággal kezelendők. Ennek ellenére úgy gondoljuk, a FIFA 18 piaci érték adatai a valós értékek jó becslését adják, így a képességekre és teljesít- 
ményre, valamint az élettani és egyéni jellemzőkre vonatkozó megfigyelésekkel együtt kutatásunk számára megfelelő alapot biztosítanak.

Ahogy az az 5. táblázatban is megjelenik, a két különböző függő változóra vonatkozó modellspecifikációk robusztussága nagy eltérést mutat. Az előzetes várakozásoknak megfelelően a logaritmizált függő változó esetében a jobb illeszkedés miatt jelentősen magasabb a modellek magyarázó ereje. A regressziós modellek futtatása előtt a potenciális torzító tényezők kiszürése érdekében végzett vizsgálódások eredményei alapján a jövőbeli fejlődési lehetőségek aggregált mérőszáma, a potential változó (az age és overall változókkal való szoros kapcsolata multikollinearitást eredményezhet), valamint a labdarúgó sérülékenységét leíró injury_prone_trait változó (az ismertebb labdarúgók alaposabb értékelése miatt) torzító hatással lehetnek a modellek eredményeire.

Emiatt, a magyarázó változókat figyelembe véve, az egyes modellspecifikációk közül kutatásunk szempontjából a II. és VI. modellek szolgáltatják a legpontosabb eredményeket, hiszen ezen specifikációk a lehető legtöbb olyan változót tartalmazzák, amelyek szignifikáns hatással bírnak a labdarúgók piaci értékére és nem torzítják a kapott eredményeket. Mindezek miatt a következőkben a logaritmizált piaci érték függő változóra vonatkozó modellspecifikációk eredményeit tárgyaljuk részletesen, külön hangsúlyt fektetve a kiemelt II. specifikációra.

5. táblázat: Az egyes modellspecifikációk általános eredményei, robusztussága

\begin{tabular}{c|c|c|c}
\hline $\begin{array}{c}\text { Függö } \\
\text { változó }\end{array}$ & $\begin{array}{c}\text { Modell- } \\
\text { specifikáció }\end{array}$ & $\mathbf{R 2}$ & $\begin{array}{c}\text { F } \\
\text { statisztika }\end{array}$ \\
\hline \multirow{4}{*}{ logvalue } & I. & 0,9740 & 50981 \\
\cline { 2 - 4 } & II. & $\mathbf{0 , 9 7 4 1}$ & $\mathbf{3 6 9 8 1}$ \\
\cline { 2 - 4 } & III. & 0,9769 & 39496 \\
\hline \multirow{4}{*}{ eur_value } & IV. & 0,9770 & 37549 \\
\cline { 2 - 4 } & V. & 0,4837 & 1296 \\
\cline { 2 - 4 } & VI. & $\mathbf{0 , 4 8 6 2}$ & $\mathbf{9 4 5}$ \\
\cline { 2 - 4 } & VII. & 0,4862 & 895 \\
\hline
\end{tabular}

Forrás: saját szerkesztés

A kutatásunk keretében futtatott regressziós modellek részletes eredményeit a topbajnokság változók példáján mutatjuk be. A Big Five bajnokságokra vonatkozó dummy változók marginális hatásait és p-értékeit a 6. táblázat foglalja össze. Összességében a négy vizsgált modellspecifikáció eredményei alapján azt mondhatjuk, hogy az öt nyugat-európai topbajnokságban játszó labdarúgók piaci értékében szignifikáns felár mutatkozik más bajnokságokban szereplő játékostársaikhoz képest, ceteris paribus.

A korábban kiemelt II. specifikáció eredményei alapján az angol Premier League labdarúgóinál a várható felár 11,60 százalék, a spanyol Primera División esetében 9,93 százalék, a német 
Bundesligában 9,68 százalék, az olasz Serie A-nál 9,80 százalék, míg a francia Ligue 1-re 5,71 százalék más bajnokságokban szereplő játékosokhoz képest, a többi magyarázó változó változatlansága mellett.

6. táblázat: A Big Five bajnokságokra vonatkozó dummy változók marginális hatásai és p-értékei

\begin{tabular}{|c|c|c|c|c|}
\hline \multirow{2}{*}{$\begin{array}{c}\text { Magyarázó } \\
\text { változó }\end{array}$} & \multicolumn{4}{|c|}{ Függő változó: logvalue, referencia: egyéb bajnokságok } \\
\hline & I. & II. & III. & IV. \\
\hline \multirow{2}{*}{ premierl } & $0,1140^{* * *}$ & $0,1160^{\star * *}$ & $0,0839^{* * *}$ & $0,0838^{* * *}$ \\
\hline & $(0,000)$ & $(0,000)$ & $(0,000)$ & $(0,000)$ \\
\hline \multirow{2}{*}{ primerad } & $0,0997^{\star * *}$ & $0,0993^{\star * *}$ & $0,0793^{\star * *}$ & $0,0798^{* * *}$ \\
\hline & $(0,000)$ & $(0,000)$ & $(0,000)$ & $(0,000)$ \\
\hline \multirow{2}{*}{ bundesl } & $0,0945^{\star * *}$ & $0,0968^{\star * \star}$ & $0,0802^{* * *}$ & $0,0794^{* * *}$ \\
\hline & $(0,000)$ & $(0,000)$ & $(0,000)$ & $(0,000)$ \\
\hline \multirow{2}{*}{ seriea } & $0,0991^{* * *}$ & $0,0980^{\star \star \star *}$ & $0,0747^{\star \star *}$ & $0,0744^{\star * *}$ \\
\hline & $(0,000)$ & $(0,000)$ & $(0,000)$ & $(0,000)$ \\
\hline \multirow{2}{*}{ frenchl } & $0,0570^{* * *}$ & $0,0571^{\star * *}$ & $0,0529^{* * *}$ & $0,0530^{* * *}$ \\
\hline & $(0,000)$ & $(0,000)$ & $(0,000)$ & $(0,000)$ \\
\hline
\end{tabular}

Forrás: saját szerkesztés

\section{KÖVETKEZTETÉSEK, KORLÁTOK ÉS TOVÁBBI KUTATÁSI LEHETŐSÉGEK}

Tanulmányunk fontos eredménye, hogy az Electronic Arts FIFA videojátékának adatbázisa alkalmas olyan statisztikai kutatások elvégzésére, amelyeket a szakirodalomban korábban alapvetően más adatbázisokra (Transfermarkt, CIES, KPMG) építve végeztek el. A kutatás egyéb jelentős eredményeként jelenik meg a labdarúgók képességeire és teljesítményére vonatkozó magyarázó változók, valamint az élettani és egyéni jellemzőket tömörítő változók hatásainak vizsgálata, amely során nagyban támaszkodtunk a témában született korábbi tanulmányok eredményeire. A vizsgált piaci értéket magyarázó tényezőkkel kapcsolatos előzetes várakozásokat és a kutatás eredményeit hasonlítja össze a 7 . táblázat.

Dolgozatunk jelentősége a labdarúgók piaci értékét befolyásoló tényezők hatásainak részletes elemzése és rendszerezése mellett a kutatáshoz felhasznált adatbázis terén alkalmazott újításokban áll. Ezen adatbázis felhasználása lehetőséget biztosított arra, hogy a korábbi kutatások eredményei alapján összegyüjtött és rendszerezett potenciális piaci értéket befolyásoló tényezők széles spektrumát górcső alá véve egy nagy elemszámú mintán vizsgálhassuk azok hatásainak irányát és erősségét.

A kutatásunkban bemutatott adatbázis kiküszöböli a korábbi cikkekben használt adatbázisok bizonyos hátrányait (kis elemszám, nehéz hozzáférhetőség, hiányos adatok, stb.), azonban néhány korlátozó tényezővel tisztában kell lenni annak, aki ezt tervezi használni. Eredményeink alapján nagy valószínüséggel kijelenthető, hogy az adatbázisban szereplő piaci értékek becsléséhez a képességekre, valamint élettani és egyéni jellemzőkre vonatkozó megfigyeléseket is fel- 
használja az Electronic Arts elemzőcsapata. Ezáltal a kutatás során kapott eredmények részben a piaci értékbecslés metodológiáját tükrözhetik, így torzítottak lehetnek, emiatt elővigyázatossággal kezelendők. Ennek ellenére fontos megjegyezni, hogy vizsgálódásunk során a Transfermarkt weboldalán fellelhető és a FIFA 18 adatbázisában szereplő becsült piaci értékek jelentős együttmozgást mutattak. Ez amellett szól, hogy a felhasznált adatok a labdarúgók piaci értékének jó becslését adják.

7. táblázat: A vizsgált magyarázó változókkal kapcsolatos előzetes várakozások és a kutatási eredmények összehasonlítása

\begin{tabular}{|c|c|c|c|}
\hline $\begin{array}{l}\text { Változó } \\
\text { típusa }\end{array}$ & Rövidítés & Várt hatás & Kutatási eredmények \\
\hline \multirow{4}{*}{$\begin{array}{l}\text { Képességekre, } \\
\text { teljesítményre } \\
\text { vonatkozó }\end{array}$} & overall & pozitív & rendkívül erős pozitív hatás \\
\hline & potential & pozitív & $\begin{array}{c}\text { torzítást okoz a modellben az overall és } \\
\text { age változókkal való szoros kapcsolata } \\
\text { miatt }\end{array}$ \\
\hline & special & pozitív & pozitív hatás \\
\hline & weak_foot & pozitív & pozitív hatás \\
\hline \multirow{5}{*}{$\begin{array}{l}\text { Élettani, egyéni } \\
\text { jellemzőkre } \\
\text { vonatkozó }\end{array}$} & age, agesq & $\begin{array}{l}\text { négyzetes, } 25-26 \\
\text { éves korig pozitív, } \\
\text { majd negatív }\end{array}$ & $\begin{array}{c}\text { négyzetes kapcsolat, } 28 \text { éves korig } \\
\text { pozitív, majd negatív }\end{array}$ \\
\hline & $\begin{array}{l}\text { injury_prone_ } \\
\text { trait }\end{array}$ & negatív & $\begin{array}{l}\text { torzított eredmény az ismertebb } \\
\text { labdarúgók alaposabb értékelése miatt }\end{array}$ \\
\hline & $\begin{array}{l}\text { kapus, vedo, } \\
\text { kozeppalyas, } \\
\text { tamado }\end{array}$ & $\begin{array}{l}\text { támadóknál } \\
\text { pozitív }\end{array}$ & $\begin{array}{c}\text { védők esetében negatív, középpályások } \\
\text { és támadók esetében pozitív, } \\
\text { referencia: kapus }\end{array}$ \\
\hline & $\begin{array}{l}\text { europa, delamer, } \\
\text { eszakamer, } \\
\text { ausztesoc, afrika, } \\
\text { azsia }\end{array}$ & $\begin{array}{l}\text { Dél-Amerika és } \\
\text { Európa esetében } \\
\text { pozitív }\end{array}$ & $\begin{array}{c}\text { Dél-Amerika esetében pozitív, Észak- } \\
\text { Amerika esetében negatív, referencia: } \\
\text { Európa }\end{array}$ \\
\hline & $\begin{array}{l}\text { premierl, } \\
\text { primerad, } \\
\text { bundesl, seriea, } \\
\text { frenchl }\end{array}$ & pozitív & erős pozitív hatás \\
\hline
\end{tabular}

Potenciális torzító tényezőként léphet fel az a jelenség is, miszerint az Electronic Arts csapata a legjobb, leghíresebb játékosok vonatkozásában sokkal alaposabb és pontosabb értékelést végez, mint az alsóbb szinteken szereplőknél. Ezáltal a kevésbé híres labdarúgókról elérhető adatok nem mindig felelnek meg a valóságnak. További korlátozó tényezö, hogy az adatok évente csak egyszer frissülnek.

Kutatásunk jó alapot biztosít a labdarúgás játékospiaci folyamatainak bővebb elemzéséhez. Úgy gondoljuk, hogy a felhasznált magyarázó változók rendkívül jó alapot biztosítanak a futballisták piaci értékének vizsgálatához, ám hivatalos piaci értékre vonatkozó adatok hiányában fontos lenne több különböző forrásból származó értékbecslések esetében is vizsgálni a potenciális hatásokat, így ellenőrizve kutatásunk eredményeinek helytállóságát. Érdemes lehet a korábbi 
játékospiaci cikkek kutatási kérdéseit áttekinteni, és ahol alkalmasabbnak tünik, ott a használt adatbázist cserélni. Megfontolandó az adatbázisok vegyes használata, például a játékosok teljesítményét az egyik, becsült értékét egy másik adatbázisból felhasználni.

\section{Felhasznált IRODALOM}

András, K. (2003): Üzleti elemek a sportban, a labdarúgás példáján. Ph.D. értékezés, Budapest, BKÁE. http://phd.lib.uni-corvinus.hu/150/1/andras_krisztina.pdf Lekérdezve: 2018. 02. 17.

András, K. (2004): A hivatalos labdarúgás piacai. 53. sz. mühelytanulmány, BKÁE http://edok.lib.uni-corvinus.hu/80/1/Andr\%C3\%A1s53.pdf Lekérdezve: 2018.02.17.

András K., Havran, Zs. és Jandó, Z. (2012): Üzleti globalizáció és a hivatásos sport: sportvállalatok nemzetközi szerepvállalása. TM 14. sz. mühelytanulmány, BCE http://unipub.lib.uni-corvinus.hu/783/1/TM14_Andras_Havran_Jando.pdf Lekérdezve: 2018. 02. 18.

Ante, L. (2019): Determinants of Transfers Fees: Evidence from the Five Major European Football Leagues. Working paper, Hamburg. https://www.researchgate.net/publication/331929212_ Determinants_of_Transfers_Fees_Evidence_from_the_Five_Major_European_Football_ Leagues Lekérdezve: 2019.04.08.

Bennett, J. M. és Flueck, J. A. (1983): „An evaluation of Major League Baseball offensive performance models" The American Statistician, 37(1): 76-82.

Berri, D. J. (1999): „Who is' most valuable? Measuring the player's production of wins in the National Basketball Association" Managerial and decision economics, 411-427.

Bühler, A.W. (2006): „Football as an international business - an Anglo-German comparison” European Journal for Sport and Society. 3(1): 25-41.

Carmichael, F., Forrest, D. és Simmons, R. (1999): “The labour market in association football: who gets transferred and for how much?" Bulletin of Economic Research, 51(2): 125-150.

Carmichael, F. és Thomas, D. (1993): "Bargaining in the transfer market: theory and evidence" Applied Economics, 25(12): 1467-1476.

Carmichael, F., Thomas, D., és Ward, R. (2000): “Team performance: the case of English premiership football" Managerial and decision Economics, 21(1), 31-45.

CIES (2019): Values https://football-observatory.com/-values-61092 Lekérdezve: 2019.03.21.

Dawson, P., Dobson, S. és Gerrard, B. (2000): "Stochastic frontiers and the temporal structure of managerial efficiency in English soccer" Journal of Sports Economics, 1(4), 341-362.

Dixon, M. és Robinson, M. (1998): "A birth process model for association football matches" Journal of the Royal Statistical Society: Series D (The Statistician), 47(3), 523-538.

Dobson, S. és Gerrard, B. (1999): “The determination of player transfer fees in English professional soccer" Journal of Sport Management, 13(4), 259-279.

Eschweiler, M. és Vieth, M. (2004): „Preisdeterminanten bei Spielertransfers in der FußballBundesliga". Zeitschrift für Betriebswirtschaft, 64(6), 671-692.

Frick, B. (2007): „,The Football Players'labor Market: Empirical Evidence From The Major European Leagues" Scottish Journal of Political Economy, 54(3), 422-446.

Frick, B. és Lehmann, E. (2001): „Die Kosten der externen Rekrutierung qualifizierten personals: Empirische Evidenz aus dem professionellen fußball" Entlohnung, Arbeitsorganisation und personalpolitische Regulierung. Munchen: Rainer Hampp Verlag, 243-63.

Havran, Zs. (2016): „A játékosvásárlás és az eredményesség kapcsolata a hivatásos labdarúgásban” Vezetéstudomány-Budapest Management Review, 47(6), 30-40. 
Kaggle (2018): FIFA 2018 Complete Player Dataset. https://www.kaggle.com/thec03u5/fifa-18demo-player-dataset Lekérdezve: 2018.01.15.

Kiefer, S. (2012): The Impact of the Euro 2012 on Popularity and Market Values of Football Player. Discussion Paper of the Institute of Organisational Economics http://ideas.repec.org/p/zbw/umiodp/112012.html Lekérdezve: 2018.02.18.

KPMG (2018): Football Benchmark. www.footballbenchmark.com/methodology/player_ valuation. Lekérdezve: 2018.07.10.

Maher, M. J. (1982): „Modelling association football scores” Statistica Neerlandica, 36(3), 109-118.

Majewski, S. (2016): „Identification of factors determining market value of the most valuable football players" Journal of Management and Business Administration, 24(3), 91-104.

Patai, C. és Popper, D. (2014): Mennyit ér egy EB-gól?: A 2012-es labdarúgó Európa-bajnokság hatásainak kvantitatív elemzése http://szd.lib.uni-corvinus.hu/8049/1/20140326110312.pdf Lekérdezve: 2018.01.16.

Preston, T. (2014): The Determinants of Football Transfer Market Values: An Age of Financial Restraint. University of Warwick http://www2.warwick.ac.uk/fac/soc/economics/current/ modules/ec331/raeprojects/0907288-ec331-a2.pdf Lekérdezve: 2018.02.22.

Reilly, B. és Witt, R. (1995): „English league transfer prices: is there a racial dimension?. Applied Economics Letters, 2(7), 220-222.

SAS (2019): SAS continues to innovate, adding AI capabilities to its analytics platform www.sas.com/ en_us/customers/scisports.html Lekérdezve: 2019.02.22.

Sæbø, O. D. és Hvattum, L. M. (2015): Evaluating the efficiency of the association football transfer market using regression based player ratings. In NIK. http://ojs.bibsys.no/index.php/NIK/article/view/246 Lekérdezve: 2018.02.05.

Speight, A. és Thomas, D. (1997): „Football league transfers: a comparison of negotiated fees with arbitration settlements" Applied Economics Letters, 4(1), 41-44.

Stern, H. (1991): „On the probability of winning a football game” The American Statistician, 45(3), 179-183.

Szymanski, S. és Kuypers, T. (1999): Winners and losers. Viking Adult.

Szymanski, S. és Smith, R. (1997): „The English football industry: profit, performance and industrial structure" International Review of Applied Economics, 11(1), 135-153.

Transfermarkt (2019): Transfermarkt. https://www.transfermarkt.de/ Lekérdezve: 2019.01.15.

Tunaru, R., Clark, E. és Viney, H. (2003): „An option pricing framework for valuation of football players" Review of Financial Economics 14 (2005) 281-295.

UEFA (2018): The European Club Footballing Landscape, Club Licensing Benchmark Report Financial Year 2017. https:/www.uefa.com/MultimediaFiles/Download/OfficialDocument/ uefaorg/Clublicensing/02/59/40/27/2594027_DOWNLOAD.pdf Lekérdezve: 2019.04.05.

van den Berg, E. W. A. (2011): The valuation of human capital in the football player transfer market. Erasmus University. https://thesis.eur.nl/pub/9763/Berg,\%20E.\%20van\%20den\%20(296332). pdf Lekérdezve: 2018.01.29.

van Ophem, H. és Ruijg, J. (2014): Determinants of football transfers (No. 14-01). Universiteit van Amsterdam, Dept. of Econometrics. https://ideas.repec.org/p/ame/wpaper/1401.html Lekérdezve: 2018.02.13.

Wicker, P., Prinz, J., Weimar, D., Deutscher, C. és Upmann, T. (2013): „No pain, no gain? Effort and productivity in professional soccer". International Journal of Sport Finance, 8(2): 124-139. 